\title{
Chapter 12 Soviet Housing Estates in Vilnius, Lithuania: Socio-ethnic Structure and Future(-Less?) Perspectives
}

\section{Donatas Burneika, Rūta Ubarevičienė and Aušra Baranuskaitė}

\begin{abstract}
This study is focused on Soviet housing estates in Vilnius. The aim of the chapter is to gain more insight into the social and ethnic profile of the residents and to highlight the trajectories of change. The analysis is based on Lithuanian census data from 2001 to 2011. Results suggest that although Soviet housing estates are less segregated than other parts of Vilnius, considerable socio-economic differences exist among residents belonging to different ethnic groups. Soviet housing estates are definitely not the most attractive residential areas, and more affluent groups increasingly prioritise residing in other parts of the city. However, that has not turned them into the neighbourhoods with the highest concentration of the least affluent population. Thus, the Soviet housing estates maintain a rather neutral position in the current residential structure of Vilnius.
\end{abstract}

Keywords Soviet housing estates · Socio-ethnic structure $\cdot$ Housing • Vilnius

\subsection{Introduction}

The post-war era of rapid industrialisation and economic growth corresponded with a massive wave of urbanisation in Central and Eastern European (CEE) countries. This took place under the communist Soviet regime. The pace of urbanisation was

D. Burneika $(\bowtie) \cdot R$. Ubarevičienè · A. Baranuskaitè Institute of Human Geography and Demography, Lithuanian Social Research Centre, Vilnius, Lithuania e-mail: donatas.geo@gmail.com
A. Baranuskaitè
e-mail: baranauskaite.ab@gmail.com
R. Ubarevičienè
Faculty of Architecture and the Built Environment, Department of Urbanism, Delft University of Technology, Delft, The Netherlands
e-mail: r.ubareviciene@tudelft.nl
(C) The Author(s) 2019
D. B. Hess and T. Tammaru (eds.), Housing Estates in the Baltic Countries,
The Urban Book Series, https://doi.org/10.1007/978-3-030-23392-1_12 
especially rapid in Lithuania. If the rate of urbanisation was as low as $30 \%$ in the pre-war period, it reached $68 \%$ by the end of the 1980s. As a consequence, a large proportion of the population of major Lithuanian cities lived in Soviet housing estates at the end of the socialist period. Since the 1990s, when the transition to a market-based economy began, the socio-spatial development of Lithuania has been characterised by several important facets: shrinkage of population, metropolitanisation, suburbanisation and increasing segregation. All of these processes have had an effect on the residential structure of Soviet housing estates.

Today, in this rapidly shrinking country, Vilnius is the main metropolitan city in Lithuania that still has potential to grow, despite the population of its central areas having dropped during the last decade (Ubarevičienè et al. 2016). In Vilnius, as in other CEE cities, the housing market was only weakly influenced by public housing policies, and, since the introduction of the market economy, cities have expanded through the process of a weakly planned and unregulated residential suburbanisation (Borén and Gentile 2007; Gentile et al. 2012; Sýkora and Ouředníček 2007). Significant spatial transformations of the whole Vilnius metropolitan region were accompanied by major changes in social structure, such as an increase in social and ethnic segregation (Valatka et al. 2016). Recent research has shown a clear relationship between the ethnic and socio-economic status of Vilnius residents (Burneika and Ubarevičienè 2016). On the other hand, these findings showed that Soviet housing estates form the most stable neighbourhoods in Vilnius city, experiencing only minor changes in their ethnic and socio-economic structure. Moreover, segregation levels were found to be relatively low in Soviet housing estates. In this chapter, we hypothesise that this stability may hide a steady downgrading of Soviet housing estates, especially in the context of the development of the city as a whole. We also expect that the trends could vary in different places, because despite their apparent uniformity, Soviet housing estates differ in terms of metropolitan location, year of construction and quality. In addition, the residential structure in Soviet housing estates should also vary, because different periods of construction corresponded to different immigration flows from other Soviet Republics and from within Lithuania.

This study is focused on Soviet housing estates in Vilnius. The aim of the chapter is to gain more insight into the social and ethnic profile of their residents and to highlight the trajectories of change. In order to get a better insight into the processes of residential differentiation, we also compare Soviet housing estates with the rest of the city. We use Lithuanian census data from 2001 to 2011. Aggregate data is used to illustrate the social and ethnic structures and to observe their changes. Data on the individual level is used to explore the interrelationships between individual characteristics. 


\subsection{Soviet Housing Estates and the Housing Structure of Vilnius}

In this study, Soviet housing estates are defined as collections of high-rise apartment buildings (mostly 5-12 storeys) built during the Soviet period (1946-1990), when intensive industrialisation followed by immigration of Russian speakers (mainly from Russia) prompted a desperate need for new housing in Vilnius. High-rise apartment buildings were a dominant type of housing built during that period (Fig. 12.1). The General Plan of Vilnius, which was part of the Lithuanian regional planning scheme approved in 1967 (Šešelgis 1996), foresaw the construction of new housing estates in massive neighbourhoods planned as separate city districts (the current administrative units, 21 in total) (Čiurlionienè 2008). The first Soviet housing estate districts appeared near the central part of the city, as well as in more distant areas, located beyond natural barriers such as forested slopes of the Neris river valley. Today, Soviet-era apartments accommodate around $62 \%$ of the Vilnius population (compared to $71.5 \%$ in 2001) and are scattered throughout the city (based on 2001 and 2011 censuses). The empirical part of this study is focused on residential areas - larger sets of Soviet housing estates - in which the absolute majority (at least 90\%) of the residents live in Soviet-era apartments. These residential areas are mostly located in the middle-west part of the city and accommodate one-third of the total population. In this study, we refer to these residential areas as housing estate districts (seven in total, Fig. 12.2) and housing estate neighbourhoods (17 in total, Fig. 12.7), depending on the spatial level used in the analysis.

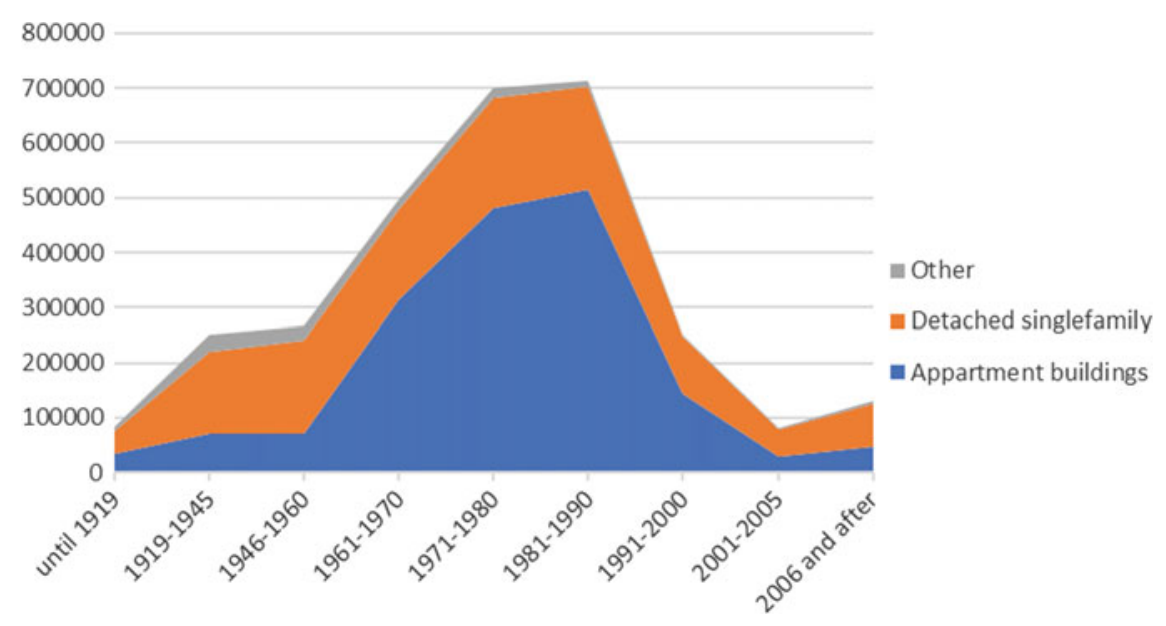

Fig. 12.1 Residential construction periods in Vilnius by housing types. Data source 2011 Lithuanian census 


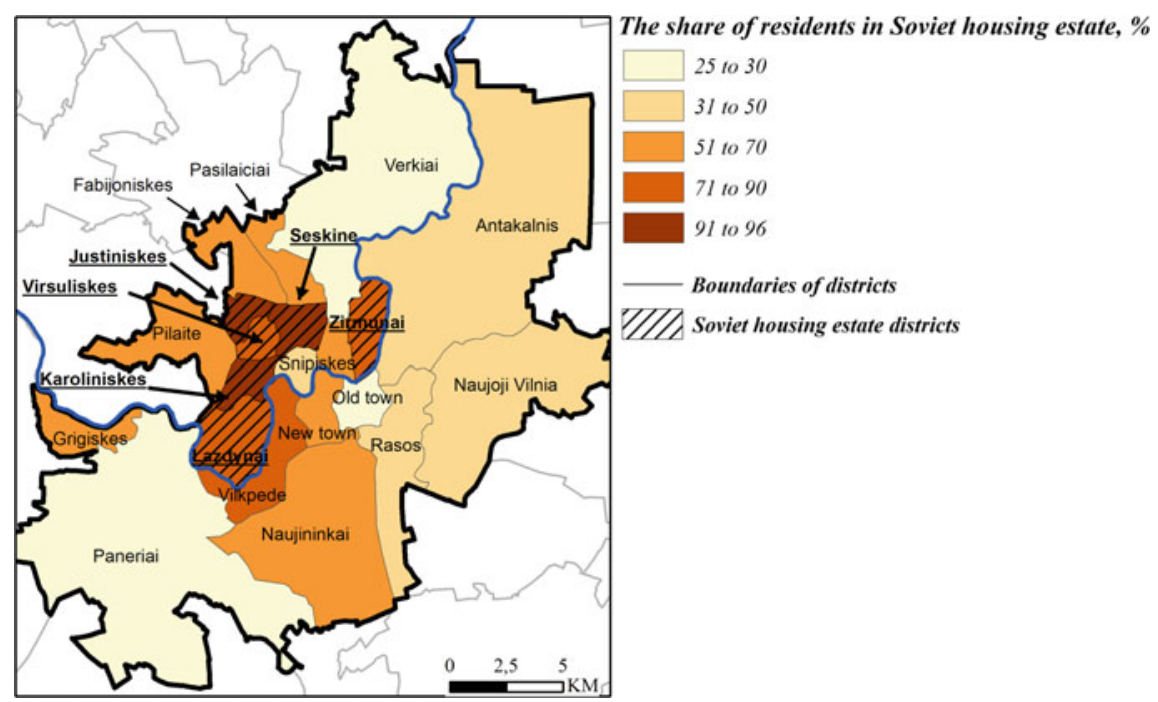

Fig. 12.2 Vilnius districts and share of residents in Soviet housing estates, 2011. Data source 2011 Lithuanian census

The quality of the housing in Soviet housing estates improves and the age decreases with distance from the city centre. As a result, their price levels are quite similar. There are a few blocks of more distant and older Soviet apartment buildings located near former industrial satellite towns. Distance from the city centre and poor physical quality make these apartment buildings the least attractive in the Vilnius housing market. Previous studies have also shown that these areas are characterised by the lowest social status and a high non-Lithuanian population (Burneika et al. 2017). Although these particular housing estates do not form large residential neighbourhoods, they may significantly affect the average indicators of some districts of Vilnius, which also incorporate more affluent suburban neighbourhoods. Furthermore, in recent decades, new housing estates have been built near Soviet-era housing districts in various parts of Vilnius. Therefore, the housing supply and residential structure of many neighbourhoods has been in flux. Soviet housing estate districts such as Karoliniskes, Justiniskes and Seskine (Fig. 12.2) were fully built up during the Soviet period, and there was hardly any room for post-Soviet development. Meanwhile, Zirmunai and Lazdynai were the districts where most of the post-Soviet construction took place in the post-reform period (Burneika 2008), thus their residential structure should have been strongly affected by mobility processes characterised by the inflow of higher social status groups.

The city centre of Vilnius consists of the Old Town (Senamiestis), New Town (Naujamiestis), former working-class neighbourhoods and some prestigious residential areas built at the end of the nineteenth century. An important feature of the Soviet housing era is working-class dormitories, which are scattered around the central parts of the city near "traditional" Soviet high-rise apartment buildings. The 
dormitories were privatised and can now be described as the low-quality housing in Vilnius. However, because they are scattered and not numerous, they do not form large areas of poverty.

The outer city forms a wide ring around the city centre and large housing estates. This zone extends both within and beyond the city limits. It has a relatively fragmented socio-economic structure and includes large, newly suburbanised areas, old collective gardens ("dacha"), former satellite industrial towns, other industrial areas and even rural settlements (some of them recently incorporated into the city limits). In Vilnius, there is a great division between the southern industrialised part, which includes former rural and suburban settlements with relatively low-quality housing, and the northern part, where new and more expensive single-family dwellings dominate. In general, the current character of the outer city is a result of post-Soviet suburbanisation. The districts where most of the post-Soviet development took place are distinguished by population growth and a decreasing share of residents in Soviet housing estates (Fig. 12.3).

Soviet housing estate districts were among the fastest shrinking districts in Vilnius (Fig. 12.3). Furthermore, the share of residents in Soviet-era apartments dropped significantly in Vilnius as a whole, as well as in each housing estate. A greater drop in population was also observed in the central pre-war working-class districts, where many wooden slums equipped with minimal communal facilities are located; however, the processes of gentrification have already changed this situation. The decline of the population in housing estates is mostly associated with the ageing population and negative net migration (due in part to suburbanisation).

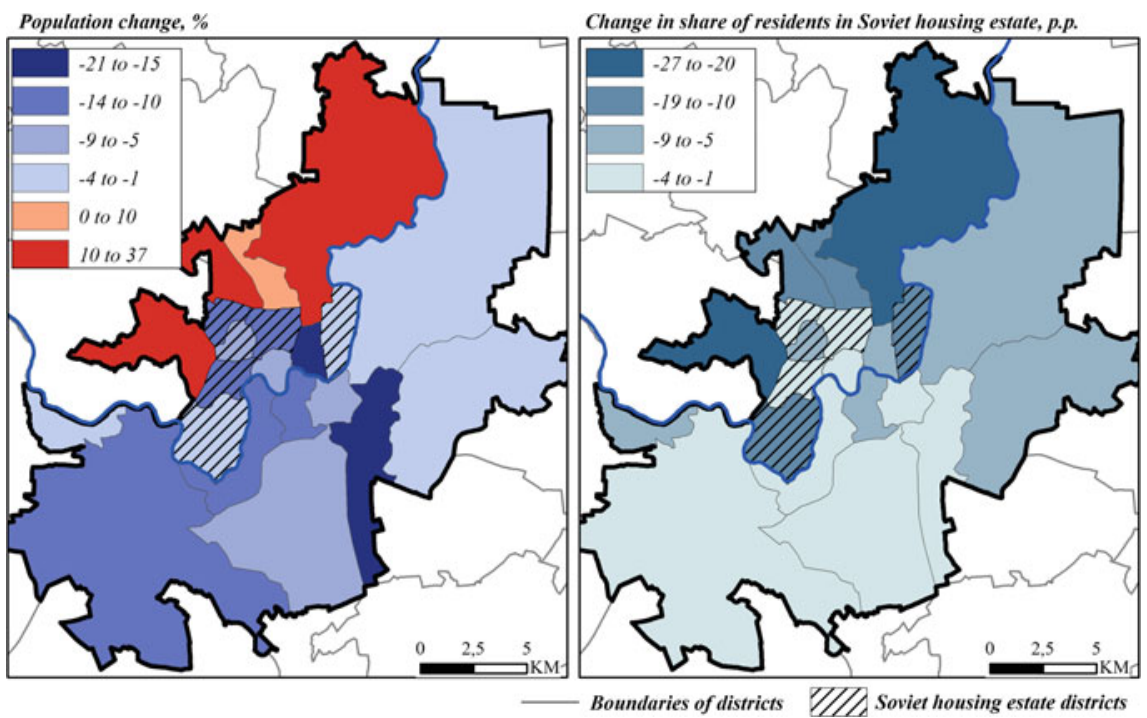

Fig. 12.3 Population change (left panel) and change in resident share in Soviet housing estates (right panel), 2001-2011. Data source 2001 and 2011 Lithuanian censuses 
A small inflow of newcomers to Soviet housing districts may be explained by two factors: limited purchasing power and varying housing preferences. It could also be associated with a limited supply of available dwellings; the household size in Soviet apartments decreases (as well as the number of residents), but the majority remain occupied. There may be a third reason: an inability of population registers to cope with the shadow rental market. In that case, we should assume that the actual social structure of housing estates might be different to that shown by the official statistics, because it is mostly young persons and families who take part in the rental market.

\subsection{Brief Overview of Previous Studies}

In this paper, we use the concept of socio-ethnic structure to determine residential differentiation, which is based on two parameters of a group: social status and ethnicity (similar to Andersson and Kährik 2016). Accordingly, we focus mainly on the parameters of age, level of education, occupational status and ethnicity. The concept of socio-ethnic inequality describes "the condition" when various ethnic groups have different social positions even if they live in the same spaces. Two main reasons for socio-ethnic inequality are mentioned in many studies, especially those in which North American and Western European cities are analysed. First, ethnic minorities often have fewer resources, which limits their ability to acquire housing. Second, discrimination in the housing market might restrict their choices (Bolt and van Kempen 2010; Semyonov and Glikman 2009). Although the processes of spatial differentiation of ethnic minorities in North American and West European cities have been studied for several decades, their findings provide little help in understanding ethnic landscapes in post-Soviet cities. At present, ethnic diversity in Western cities is often regarded as a result of postcolonial processes, while in the post-Soviet cities, particularly in the Baltic countries, ethnic diversity can mostly be deemed the result of colonialism. Ethnic minorities that migrated to Baltic cities during the Soviet period were not in disadvantaged socio-economic positions. This is likely to have changed after post-communist reforms were introduced, which included property restitution and the strengthening of the position of national languages in public and institutional life.

In Lithuania, one of the first attempts to gain more insights into the social and ethnic structure of housing estates was made by Vanagas (1996). He presented the results of sociological surveys that illustrated differences of place identities among the residents of various districts in Vilnius. Vanagas' studies showed differences in the attractiveness of centrally planned housing districts, with Antakalnis, Zirmunai and Lazdynai ranked among the most attractive districts (together with the city centre), while districts that were further away from the city centre and of later construction were ranked the least attractive. Unfortunately, these surveys did not analyse the social or ethnic profile of the residents. More recent survey-based research of Krupickaite (2014) showed that residents of typical Soviet-era high-rise apartments (Karoliniskes district was used as a case study) are the most dissatisfied 
with their dwellings, compared to residents of other parts of Vilnius. The findings of Krupickaite (2014) suggest that faster social degradation is expected in housing estates, as their population is ageing and has lower levels of education and income. In addition, the residents of Soviet housing estates are the least mobile, which means that their social structure changes slowly. Although a few other studies on residential differentiation in Vilnius have been carried out (Tereškinas et al. 2013; Žilys 2013), they did not focus exclusively on Soviet housing estates, and thus their results provide little insight into the social and ethnic structure of the housing estates and differences between neighbourhoods. Most studies mentioned in this overview find that the ethnic and social composition is quite homogenous in housing estates compared to other parts of Vilnius.

\subsection{Data and Methods}

The empirical part of this chapter is focused on residential areas in Vilnius in which the absolute majority (at least 90\%) of the residents live in Soviet-era apartments. Analysis is based on a data from 2001 to 2011 Lithuanian censuses. District-level (Seniūnija or LAU 2 statistical regions) data is used to analyse socio-ethnic structure and its changes between 2001 and 2011. Data aggregated on smaller (neighbourhood) level ${ }^{1}$ is used to analyse 2011 census data in more detail. Finally, individual-level data is used to explore the relationships between individual characteristics. Aggregate data is mostly analysed using cartographical techniques, with logistic regression used for individual-level analysis. The following variables describing the population structure are included in the analyses: age, ethnicity, level of education and occupational group. The combination of cartographical and statistical methods gives a good insight into the residential structure of Soviet housing estates and allows us to uncover trends in their changes.

We use self-reported data on ethnicity to analyse residential differentiation of Lithuanian, Polish and Russian ethnic groups. These are the main ethnic groups in Vilnius and in Lithuania overall. Occupational groups, according to the ISCO categories, ${ }^{2}$ are used as a proxy for socio-economic status, with managers and professionals representing groups with higher socio-economic status, and unskilled and low-skilled workers representing groups with lower socio-economic status. Although occupation does not always reflect social status or income, the national labour force survey of 2010 (Statistics Lithuania 2014) confirmed that the differences in incomes between occupational groups are substantial in Lithuania.

\footnotetext{
${ }^{1}$ This is an intermediate level between census tracts and districts in Vilnius. Based on the prevailing housing type, we created 65 smaller neighbourhoods in Vilnius. These were the smallest possible territorial units for which we could request Statistics Lithuania provide us with individual-level data, which they could only do for the 2011 census.

${ }^{2}$ We use the International Standard Classification of Occupations (ISCO) provided by the International Labour Organization (2012).
} 


\subsection{Socio-ethnic Differentiation and Trajectories of Change in Vilnius}

This section discusses the socio-ethnic structure of housing estates in Vilnius. Four indicators are analysed: ethnic, age, level of education and occupational structure.

\subsubsection{Ethnic Structure}

Currently, Lithuanians comprise $63.3 \%$ of the total population in Vilnius, and the largest ethnic minority groups are Poles (16.5\%) and Russians (11.9\%) (based on the 2011 Lithuanian Census). All together, the seven housing estates that we analyse in this chapter have the same proportion of Lithuanians, a slightly smaller proportion of Poles (16.0\%) and a higher proportion of Russians (13.1\%) than city average. It can be seen in Fig. 12.4 that although the share of Lithuanians has been increasing throughout the districts of Vilnius since 2001, this increase has been smaller in housing estates. Meanwhile, the most visible increase in the share of Lithuanians was observed in the city centre (due to gentrification processes) and in the suburban zones. These are the areas where the most post-Soviet development took place. Consequently, ethnic segregation on a city-wide scale-Soviet housing estates districts versus the rest of the city-is growing. Among housing estates, the highest increase of Lithuanians was observed in Zirmunai-the most centrally located Soviet housing districts-where large housing projects were developed during recent decades. Therefore, it is difficult to assess how much of this change in the ethnic composition of Zirmunai has been determined by changes in the Soviet-era apartments themselves.

Russians are overrepresented in all Soviet housing estates compared to the city average. However, Russians are mostly concentrated in the southern industrial districts of mixed housing (housing estates, dilapidated pre-war working-class dwellings, and Soviet dormitories). Poles are also concentrated in the southern part of the city, but unlike the Russians, their share is not high in Soviet housing districts. The share of both Russian and Polish minorities is decreasing throughout the districts of Vilnius (at the expense of a growing share of Lithuanians). However, there is one exception: an increase in the share of Poles in Karoliniskes, which is likely to be related to lower levels of Lithuanian newcomers; it is the oldest among analysed housing estate (of similar age and housing design to Zirmunai and Lazdynai) with a relatively unfavourable location. Moreover, both Zirmunai and Lazdynai received prizes for urban design in the Soviet era, which probably makes Karoliniskes the least attractive place for more affluent, middle-class newcomers. Given that Poles occupy the worst positions in the Vilnius labour market (Burneika and Ubarevičienè 2016), this increase possibly indicates that the district attracts the least affluent, lower middle-class newcomers to housing estates. 
12 Soviet Housing Estates in Vilnius, Lithuania ...

Share of Lithuanians, \%

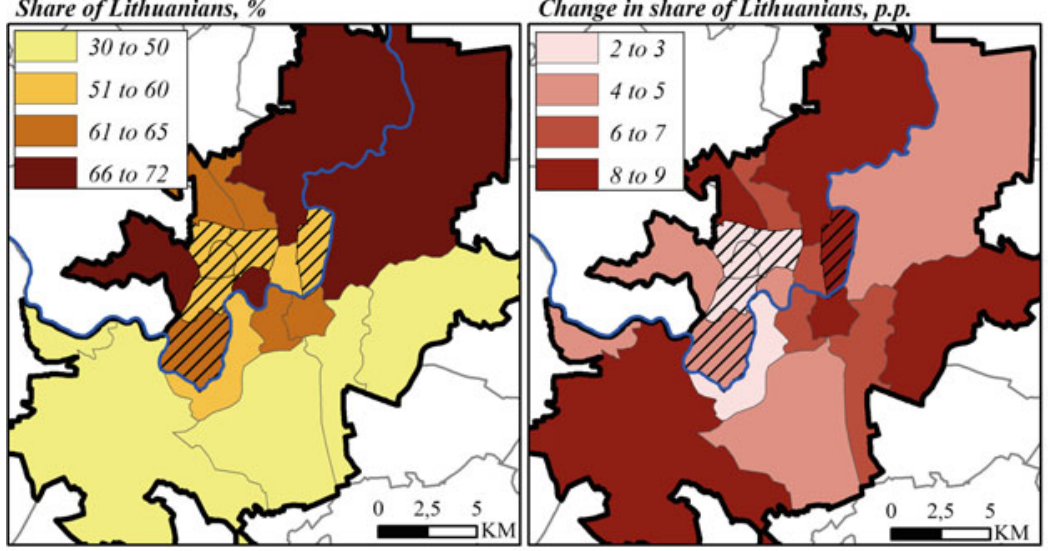

Share of Russians, \%

Change in share of Russians, p.p.
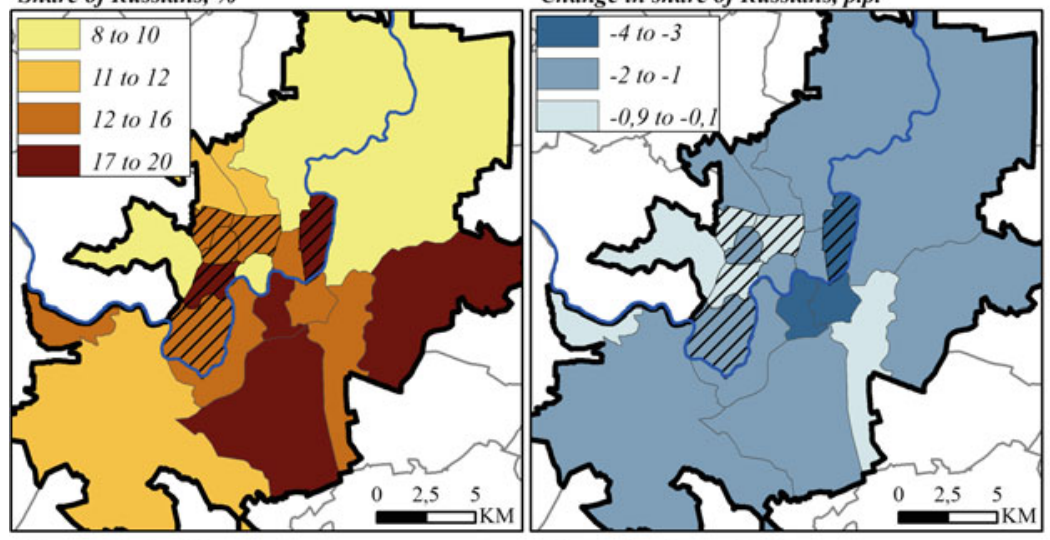

Share of Poles, \%

Change in share of Poles, p.p.

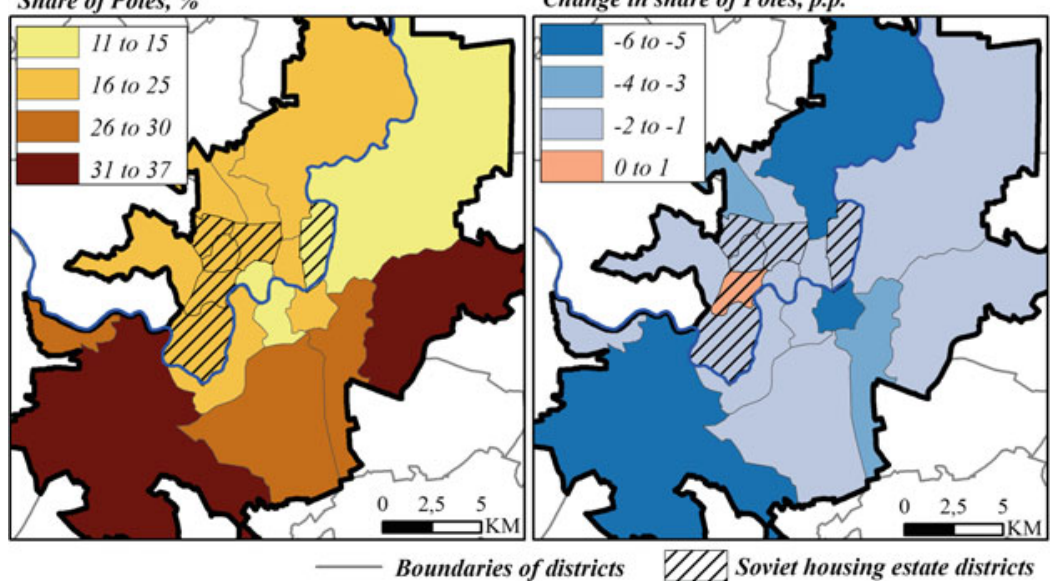

Fig. 12.4 Ethnic landscape of Vilnius: Lithuanians, Russians and Poles, 2001-2011. Data source 2001 and 2011 Lithuanian censuses 


\subsubsection{Age Structure}

Figure 12.5 demonstrates that in 2001 the highest share of the working-age population could be found in the northern part of Vilnius, while pensioners were overrepresented in the more central districts. To a large extent, this fragmentation persisted in 2011. In housing estates, the share of working-age population was quite high in 2001, but the decrease in this share has been the fastest. Soviet housing districts also experienced an abrupt increase in their share of the elderly population. In 2001 the highest share of pensioners could be found in the oldest and more centrally located housing estates. Meanwhile (unsurprisingly), the lowest share of pensioners
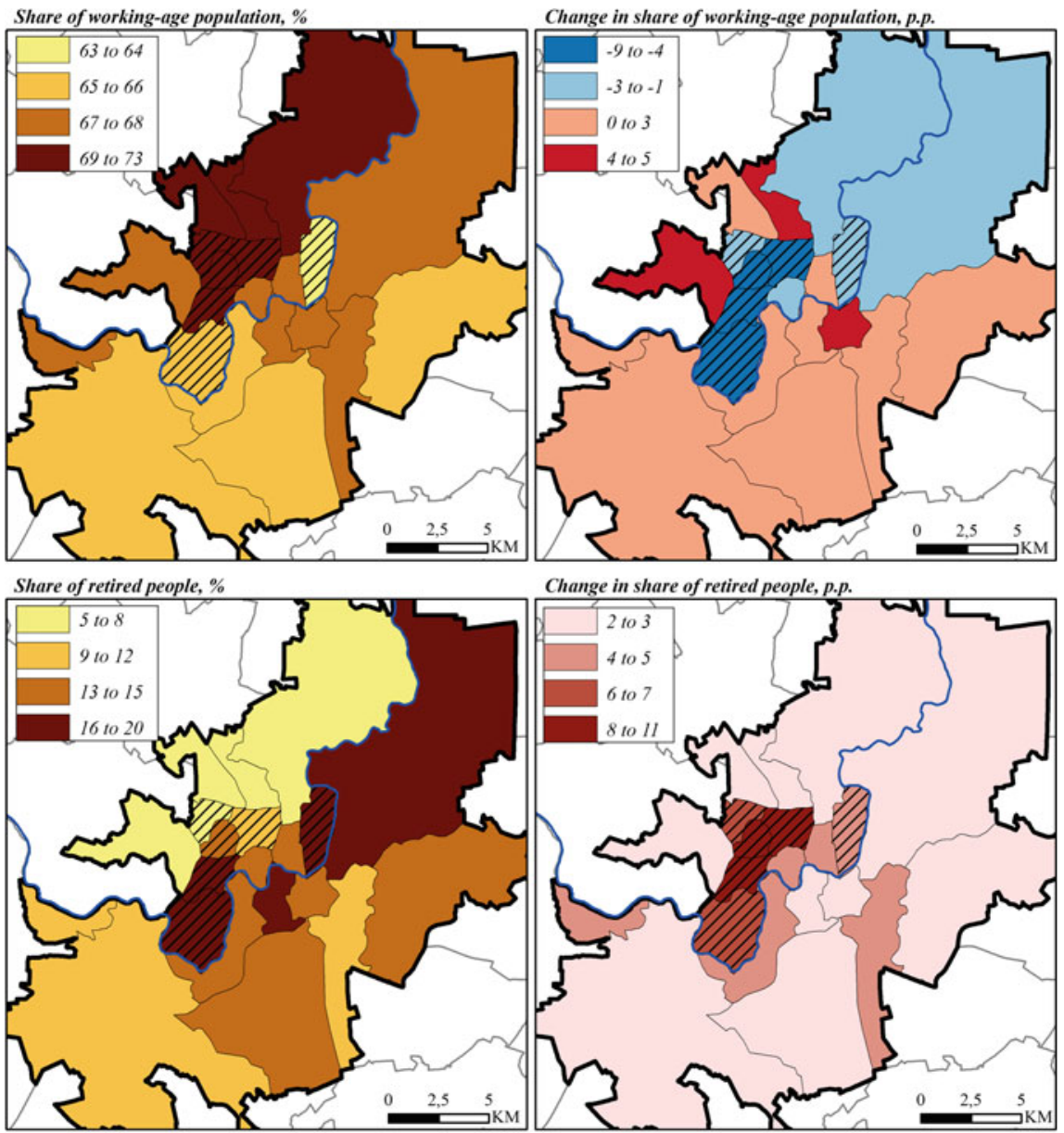

Change in share of retired people, p.p.

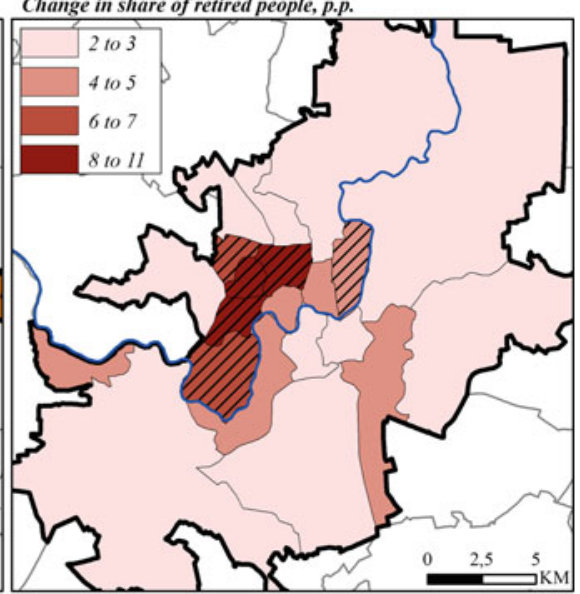

Boundaries of districts DID, Soviet housing estate districts

Fig. 12.5 Age structure of Vilnius: working-age adults and pensioners, 2001-2011. Data source 2001 and 2011 Lithuanian censuses 
could be found in the newest housing estates, located to the north-west of city centre. We can state that changes in age structure were greater than changes in ethnic composition in housing estates. Therefore, this confirms our earlier expectations that it is the immobile and "ageing in place" population that primarily determines socio-ethnic changes in housing estates. However, we may expect more profound changes in socio-ethnic composition in housing estates in the coming decades, when residential differentiation will be facilitated by a natural population decline.

\subsubsection{Educational Attainment}

The level of education (measured by educational levels among residents aged 10+) can also indirectly characterise the social structure of a population. Figure 12.6 illustrates that the residents of housing estates are distinguished by a relatively high level of education, whereas residents with lower education levels are overrepresented in the southern part of the city. Therefore, in terms of the social environment, it could be assumed that more educated and prosperous groups should find housing estates quite attractive to live in. However, the change in the share of residents with tertiary education indicates that housing estates are less attractive for highly educated newcomers compared to the post-Soviet spaces. The lowest increase in the share of residents with tertiary education was detected in Karoliniskes, confirming our previous suggestions concerning the low desirability of this older Soviet housing district. Our results suggest that all Soviet housing estates can be characterised as slowly deteriorating areas, although a fairly large proportion of well-educated residents remain, especially when compared with the southern part of the city.

\subsubsection{Occupational Structure}

Figure 12.7 illustrates that the higher occupational groups tend to concentrate in the northern part of the outer city and in the inner city. Meanwhile, the lower occupational groups tend to concentrate on the southern part of the city. Soviet housing estates do not stand out in terms of concentration of higher- or lower occupational groups, thus they can be characterised as having a fairly average occupational structure. According to census data, between 2001 and 2011 the number of Vilnius residents with higher occupational status increased by $41 \%$ (from 83.4 to 117.8 thousand). However, it can be seen in Fig. 12.6 that the increase was smaller in housing estates (it must be noted that Soviet housing estates, like many other districts, experienced declining concentrations of residents with lower occupational status). This means that Soviet housing estates have a relatively declining structure of occupational status in the context of the whole city. We can state that neither immigration nor social mobility upgrades the social status of housing estates. This is consistent with our previous findings. 


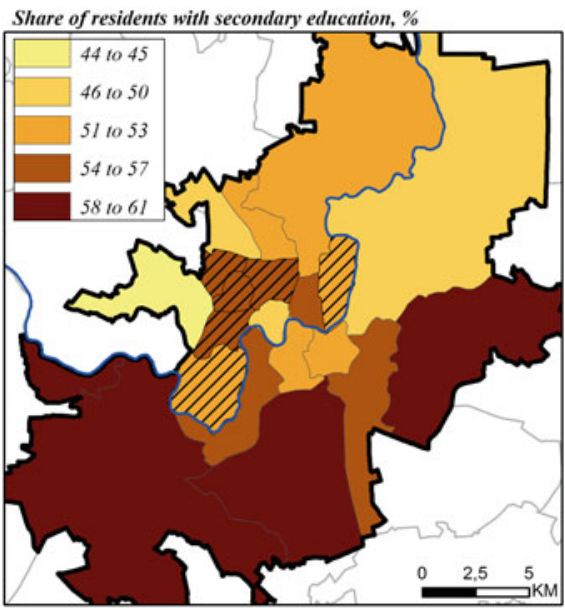

Change in share of residents with secondary education, p.p.

Share of residents with tertiary education, $\%$
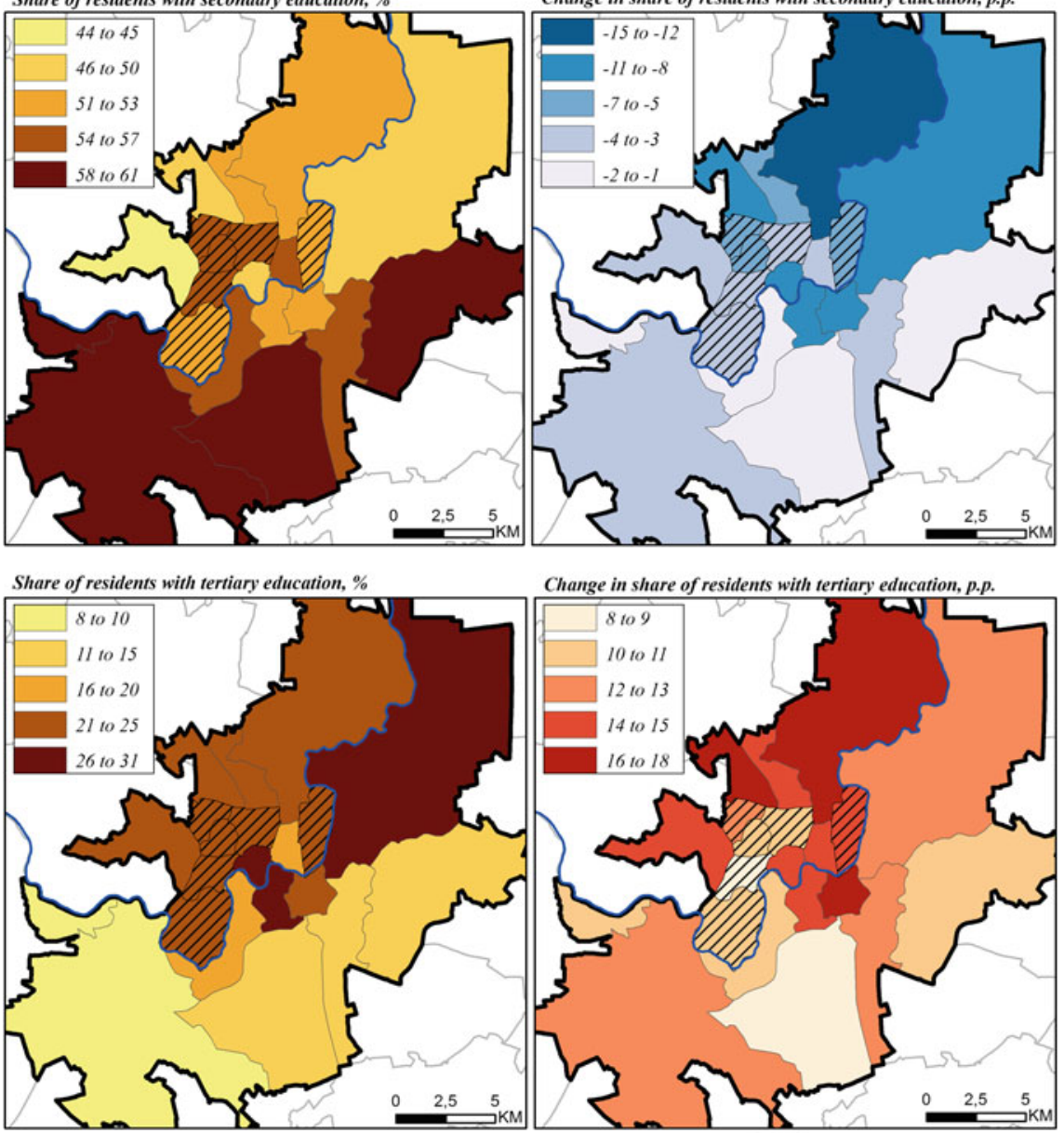

Change in share of residents with tertiary education, p.p.

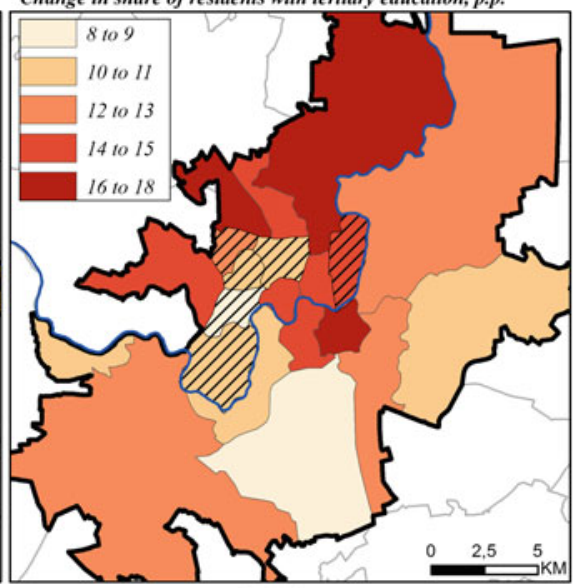

Boundaries of districts D/D, Soviet housing estate districts

Fig. 12.6 Educational structure of Vilnius: secondary and tertiary education, 2001-2011. Data source 2001 and 2011 Lithuanian censuses

To sum up, we may state that all indicators: ethnicity, age, level of education and occupational structure indicate limited residential mobility ('in-' and 'out-' flows) in housing estates. Although Soviet housing estates have become less attractive for the younger population and higher socio-economic status groups, they are not the poorest residential areas of Vilnius. We observe a slow social decline in housing estates compared to the whole city, where the social structure is improving faster due to immigration and social mobility. It should be noted that the social decline in housing estates is relative and most of them have a fairly average social structure on a city-wide scale, whereas the most prosperous and least affluent population groups are overrepresented in other parts of Vilnius. The cost of living in Soviet housing 


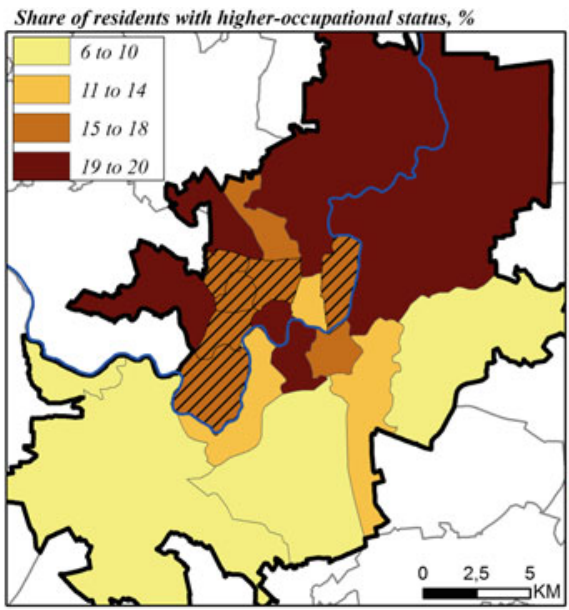

Change in share of residents with higher-occupational status, p.p.

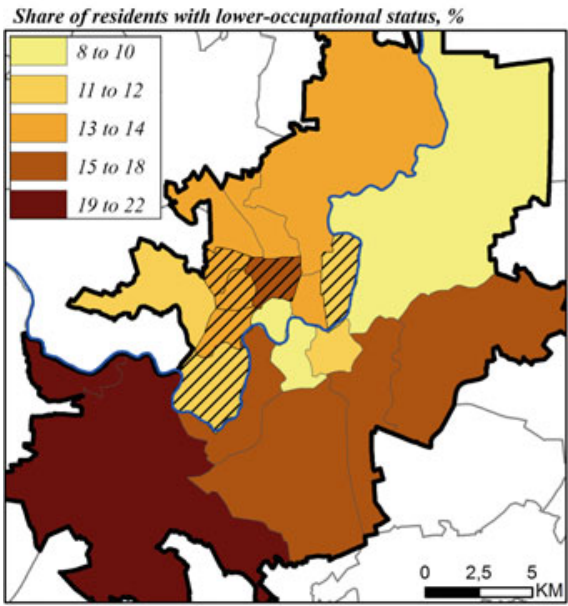

Change in share of residents with lower-occupational status, p.p.

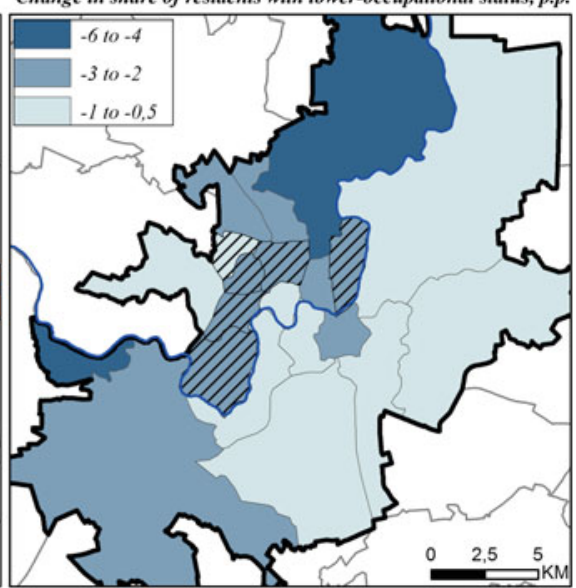

- Boundaries of districts $\mathrm{VIV}$ Soviet housing estate districts

Fig. 12.7 Higher and lower occupational groups in Vilnius, 2001-2011. Data source 2001 and 2011 Lithuanian censuses

estates is likely to be too high for the lowest-income households to move in. On the other hand, existing heating cost compensation - an instrument of state social policy ${ }^{3}$ - and the ageing population's preference to remain in place, frame the socio-economic and ethnic structure of these districts.

\footnotetext{
${ }^{3}$ According to the policy, households should not spend more than $20 \%$ of their income on heating costs. Otherwise for low-income households (e.g. pensioners) in older apartments, built during the Soviet period, heating costs would exceed their income in winter time. As a result of this compensation, lower income groups can afford to live in relatively expensive and large apartments.
} 


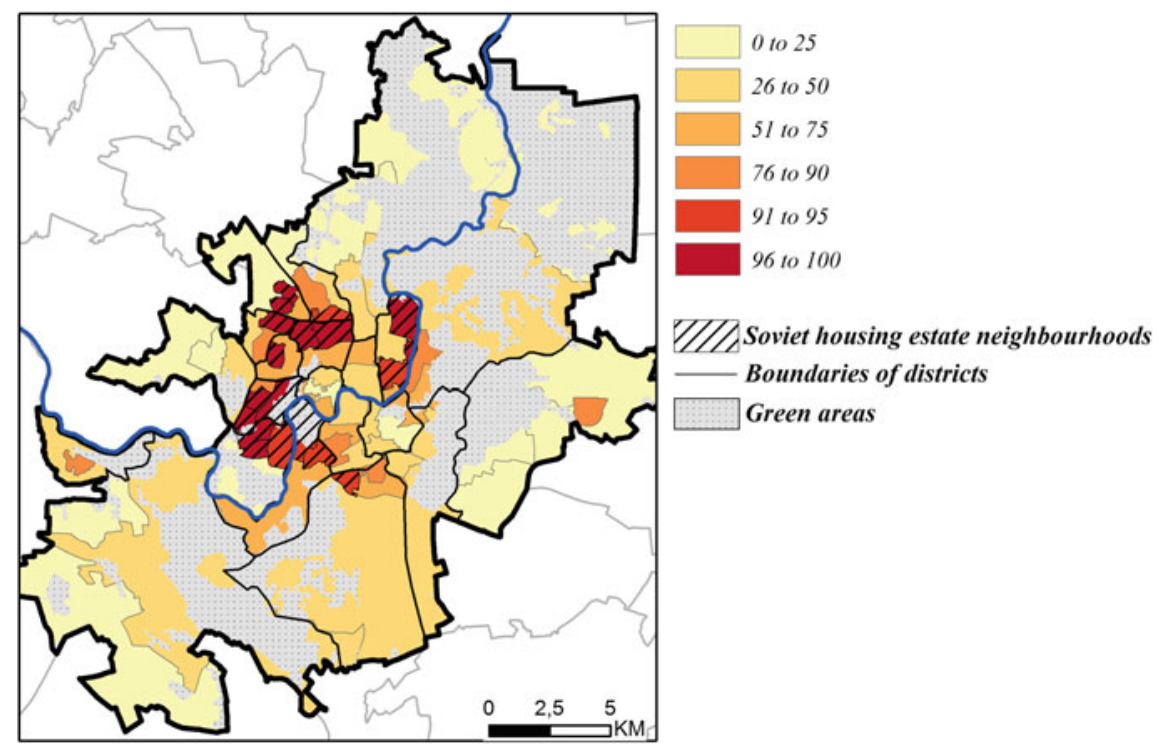

Fig. 12.8 Share of residents in Soviet apartment buildings in Vilnius by neighbourhood, 2011. Data source 2011 Lithuanian census

\subsection{Detailed Spatial Level Analysis: Socio-ethnic Composition in 2011}

The results above suggest that in many cases housing estates do not stand out significantly from the overall context of Vilnius. However, there are many smaller residential areas that do not form separate districts, but where the absolute majority of residents live in Soviet-era apartments. More detailed spatial level analysis should help to gain more insight into socio-ethnic differentiation and to better access the characteristics of housing estate residents within the city. In addition, detailed spatial level analysis should help us to understand to what extent changes in socio-ethnic composition of housing estates are related to the post-Soviet infill of residential development and to what extent they are determined by renovation within apartment buildings. Therefore, we will now use neighbourhood-level ${ }^{4}$ data to give an overview of the socio-ethnic structure of Soviet housing neighbourhoods.

Figure 12.8 illustrates the share of residents in Soviet-era apartment buildings across 65 neighbourhoods in 2011. It also indicates housing estate neighbourhoods - areas in which at least $90 \%$ of residents live in Soviet housing estates. There are almost no pre- and post-Soviet residential buildings in the majority of housing estates and there is little space for new construction. The majority of new buildings

\footnotetext{
${ }^{4}$ Described above in Data and Methods section.
} 
were built in spaces outside housing estates. The development of the city has been mostly in a westbound direction since the nineteenth century, therefore the distance between the Old Town and the various Soviet housing neighbourhoods varies greatly. In Zirmunai district the nearest housing estates are reachable by foot, whereas these neighbourhoods are a few kilometres away from the Karoliniskes and Lazdynai districts, separated by a river valley and having only two transport junctions for the city centre.

\subsubsection{Ethnic Structure}

Figure 12.9 illustrates the ethnic landscape of Vilnius in 2011 in more detail. Although clear ethnic segregation can be seen at the city level, housing estates do not differ from the general context of the city, especially in the case of Lithuanians and Poles. There are very small variations in the share of these two groups in housing estates (analysed in previous sections). The greatest differences are in southern, more industrial neighbourhoods in Vilkpede and, especially, Naujininkai, which include a lot of dormitories, some khrushchëvka, and even older Soviet buildings that cannot be separated from typical Soviet housing estates in our analysis. It is the least Lithuanian Soviet apartment space in Vilnius. The share of Russians, on the other hand, is somewhat higher and varies more inside Soviet housing districts. Russians are overrepresented in the older housing estates (in the Zirmunai, Lazdynai and, especially, Karoloniskes districts) and more central locations, which are close to the industrial areas. The distribution of Russians is most likely related to historical factors as these neighbourhoods were established during a time of intense industrialisation. It can be said that the newer the housing

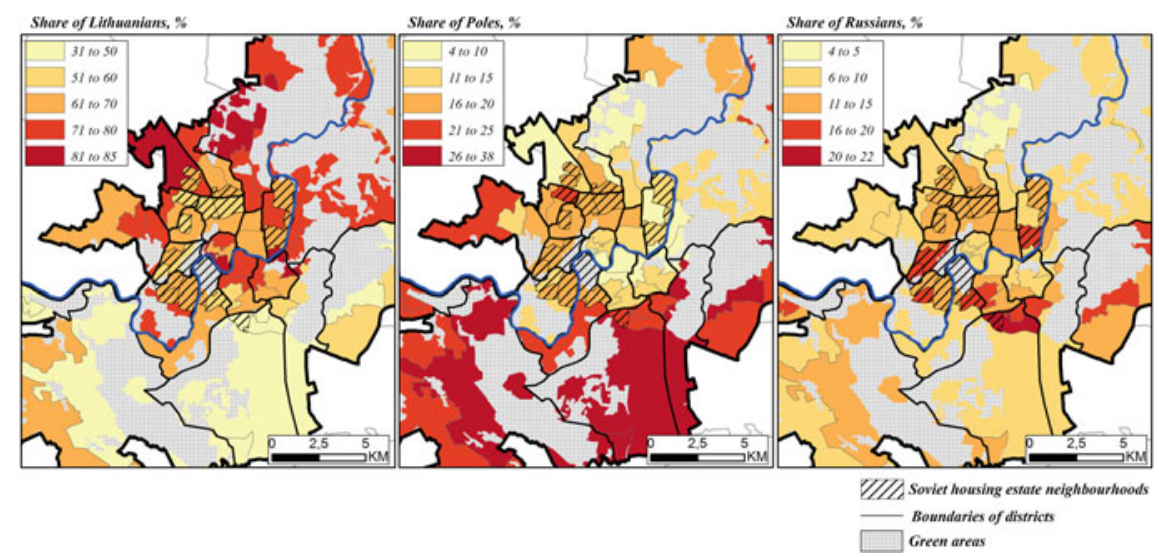

Fig. 12.9 Ethnic landscape in Vilnius by neighbourhood, 2011. Data source 2011 Lithuanian census 
estate, the lower the share of Russians. Post-Soviet spaces built in between the Soviet housing districts are overrepresented by Lithuanians, who have dominated among the newcomers since 1991. In general, these findings are in line with the findings of other Baltic studies (Tammaru et al. 2016; Krišjāne et al. 2016), though the share of minorities is much lower in Vilnius. There are no typical housing estate neighbourhoods in Vilnius, i.e. those in which the two main ethnic minorities would form the majority of population.

\subsubsection{Age Structure}

In Soviet housing estates, the spatial distribution of the population by age correlates with the construction period of the neighbourhoods. Figure 12.10 shows that the oldest residents concentrate in the oldest Soviet housing neighbourhoods (right panel), residents who just exceed retirement age are overrepresented in more distant housing estates (middle panel), and young groups dominate outside of these neighbourhoods, mostly in the inner city and suburbs (left panel). The pattern of such distribution illustrates the construction cycles of the city in the post-war period. Neighbourhood-level analysis shows that districts with mixed housing types (e.g. in Zirmunai or Lazdynai) have experienced more profound changes in their ethnic and age structures, due, above all, to the new post-Soviet development. In general, housing estates within a district share similar compositions of population, which confirms the hypothesis that construction age is a decisive factor.

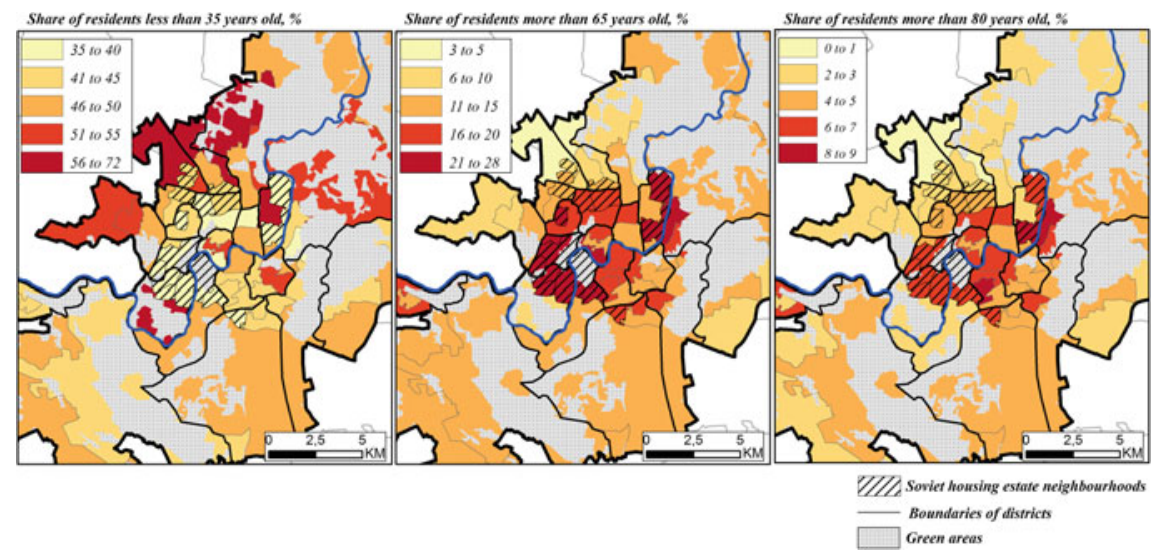

Fig. 12.10 Age groups in Vilnius by neighbourhood, 2011. Data source 2011 Lithuanian census 


\subsubsection{Educational and Occupational Structure}

In terms of share of residents with tertiary education, housing estates have an average position in Vilnius (Fig. 12.11, left panel). There is a significant overrepresentation of highly educated residents in the inner city. The higher share is observed in the most centrally located housing estate in Zirmunai, and underrepresentation is detected in the southern part of the city. The spatial distribution of higher occupational groups (right panel) overlaps, in most cases, with the distribution of residents with tertiary education. Soviet housing estates are also not exceptional in terms of the share of residents with lower occupational status: none of them has a particularly high or low proportion of lower occupational groups (middle panel). In addition, our analysis showed (maps not shown) that in terms of employment by economic sector (industry, traditional services and business services) Housing estates again do not stand out from the overall context of Vilnius. On the contrary, some other urban areas have rather clearer "specialisations".

The results of the neighbourhood analysis reaffirm that housing estates occupy relatively average positions in terms of the social composition of Vilnius. The more outstanding feature of these areas is an overrepresentation of older population groups. The elderly, who are the least mobile group of the residents prevent possible inflow of other population groups, resulting in slower changes to the social composition of Soviet housing estates. Age composition may also have an impact on the development of housing estates in the future-e.g. the initiation of renovation projects depends on the activity and support of the local population (though the main initiator of renovation projects has been the city government since the reform of 2013). A recent study by Ščerbinskaitė and Krupickaitė (2017) demonstrates that the spatial distribution of renovation projects in Vilnius is highly uneven. There are more renovation projects being implemented in Soviet apartment

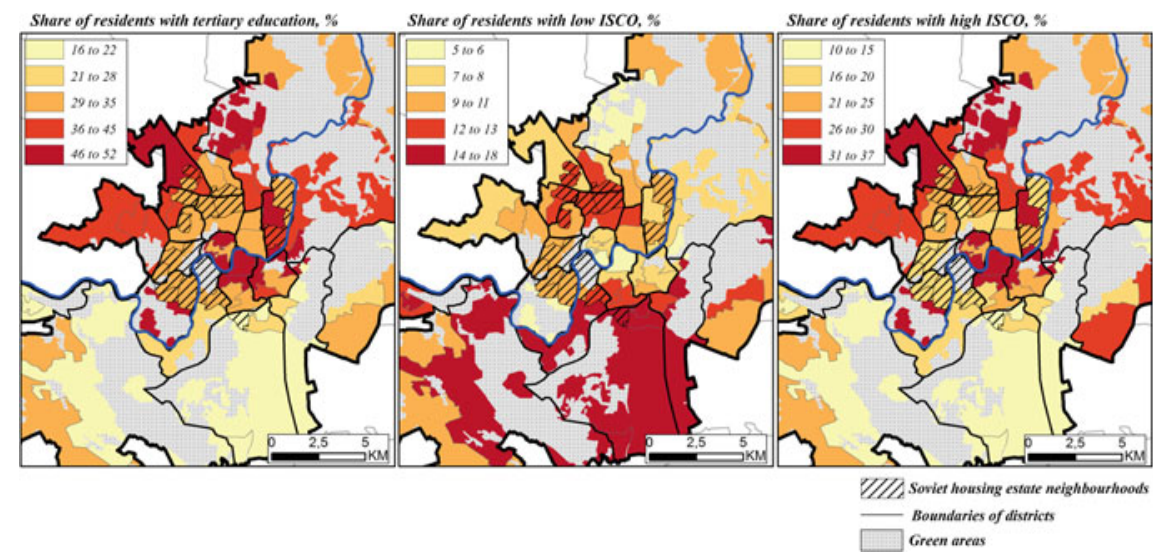

Fig. 12.11 Tertiary education and occupational groups in Vilnius by neighbourhood, 2011. Data source 2011 Lithuanian census 
buildings that is situated close to the city centre (i.e. in Zirmunai or Antakalnis). Very few houses of similar age and design were renovated in Karoliniskes and neighbouring areas; the share of renovated buildings is five to six times lower there.

\subsection{Individual-Level Analysis: Social Dimensions of Ethnic Differentiation in Soviet-Era Apartments}

A large proportion of Vilnius residents live in Soviet-era apartments that do not form part of the larger neighbourhoods or districts that have been analysed in previous sections. Although, our aim was to gain more insight into the profile of the residents in those homogenous and large Soviet estates, it would also be interesting to know whether the residents of Soviet-era apartments are different from those living in other types of housing in Vilnius. Many previously analysed areas have at least a small proportion of non-Soviet buildings. Therefore, in this section we will analyse data that is not linked to districts or neighbourhoods; using individual-level data, we will explore the characteristics of residents according to their housing type of residence (residents that live in Soviet-era apartments versus other housing types). We expect that individual-level analysis will reveal greater differences between the residents.

First, we aggregated individual-level data to show the profile of residents that lived in Soviet-era apartments and those that lived in other types of housing in Vilnius in 2011 (Table 12.1). Results show that on average, there are more females, more elderly people, fewer ethnic Lithuanians and more Russians, as well as less educated, less skilled and more unemployed residents in Soviet-era apartments compared to the rest of the city. Although, these results are in line with the findings of the previous sections, the differences here are more pronounced.

To further explore the socio-spatial differentiation within Vilnius, we present the results of binary logistic regression models that estimate the probability that a Vilnius resident lives in Soviet-era apartments rather than other housing types (Table 12.2). Census data from both 2001 and 2011 are analysed.

First, the model for 2011 shows that the probability of living in Soviet-era apartments strongly increases with age: residents over 65 years old are 3.1 times more likely to live in Soviet-era apartments than in a different type of dwelling. It also shows that controlling for other characteristics, Lithuanians are less likely and Russians more likely to live in Soviet-era apartments. Moreover, highly educated people are less likely to live in Soviet-era apartments. In addition, the model shows that with increasing occupational status the likelihood of living in Soviet-era apartments decreases, while there is a higher probability of being unemployed if living in a Soviet-era apartment. In general, the residents of Soviet-era apartments are slightly less socially affluent and more ethnically mixed than the Vilnius average.

The second model shows the residential differentiation in 2001. The comparison of the two models highlights some important trajectories of change in the social and ethnic profile of the residents in Soviet-era apartments compared to the rest of the 
Table 12.1 Composition of the population of Soviet-era apartments and of Vilnius as a whole, 2011

\begin{tabular}{|c|c|c|c|}
\hline Category & $\begin{array}{l}\text { Soviet housing } \\
\text { estates, \% }\end{array}$ & Other types of housing & Vilnius total, \% \\
\hline Male & 43.6 & 46.6 & 44.7 \\
\hline Female & 56.4 & 53.4 & 55.3 \\
\hline Age up to 35 & 39.0 & 53.4 & 44.4 \\
\hline Age $35-49$ & 20.0 & 22.6 & 21.0 \\
\hline Age $50-64$ & 21.0 & 15.3 & 18.8 \\
\hline Age above 65 & 20.1 & 8.8 & 15.8 \\
\hline Lithuanians & 59.6 & 69.2 & 63.3 \\
\hline Poles & 17.4 & 15.1 & 16.5 \\
\hline Russians & 14.2 & 8.2 & 11.9 \\
\hline Primary education & 9.1 & 9.8 & 9.4 \\
\hline Secondary education & 56.1 & 46.5 & 52.6 \\
\hline Tertiary education & 34.7 & 43.7 & 38.0 \\
\hline Low-occupational status ${ }^{*}$ & 22.7 & 15.8 & 20.0 \\
\hline Middle-occupational status ${ }^{*}$ & 25.2 & 21.6 & 23.8 \\
\hline High-occupational status ${ }^{*}$ & 37.0 & 50.2 & 42.2 \\
\hline Unemployed $^{*}$ & 15.1 & 12.3 & 14.0 \\
\hline
\end{tabular}

Data source 2011 Lithuanian census. *From economically active population

city. First, the model for 2001 shows that although, as in 2011 , the probability of living in Soviet-era dwellings increases with age, the likelihood of the older age groups living in such apartments was not as high in the past. Apparently, a large proportion of the population approached retirement age just prior to 2011. This also corresponds to the period of construction of the Soviet housing estates (mostly late $60 \mathrm{~s}-80 \mathrm{~s}$ ). The model also shows that ethnic minorities were relatively less likely to live in Soviet-era dwellings than they were in 2011. In addition, Soviet-era apartments had a relatively more favourable socio-economic structure: residents were more likely to have tertiary education and higher occupational status in 2001 compared to 2011; the likelihood of living in Soviet-era dwellings decreased the most for the higher occupational groups, illustrating that Soviet-era apartments are losing their most affluent populations.

The results of the regression models confirmed our previous observations and gave us more insight into the relationships between individual characteristics. In addition, the results clearly show the direction of change and that residential differentiation (specifically, differentiation between the residents living in Soviet-era apartments and those living in other dwelling types) is significantly and rapidly increasing. This increase is to the disadvantage of Soviet-era dwellings.

Next, we ran multinomial logistic regression to explore the differences between individuals belonging to particular ethnic groups in Soviet-era apartments in 2011 (Table 12.3). In this model, the dependent variable indicates the ethnic group: 
Table 12.2 Logistic regression model of Soviet housing estate residents in Vilnius, 2011 and 2001, at the individual level

\begin{tabular}{|c|c|c|c|c|c|c|}
\hline \multirow[b]{2}{*}{ Variables } & \multicolumn{3}{|l|}{2011} & \multicolumn{3}{|l|}{2001} \\
\hline & B & SE & EXP (B) & B & SE & EXP (B) \\
\hline \multicolumn{7}{|c|}{ Gender $($ reference $=$ male $)$} \\
\hline Female & 0.083 & 0.006 & 1.087 & 0.068 & 0.006 & 1.070 \\
\hline \multicolumn{7}{|c|}{ Age (years) $($ reference $=$ up to 35$)$} \\
\hline $35-49$ & 0.137 & 0.008 & 1.147 & -0.169 & 0.008 & 0.844 \\
\hline $50-64$ & 0.544 & 0.009 & 1.723 & 0.449 & 0.010 & 1.566 \\
\hline Above 65 & 1.132 & 0.010 & 3.101 & 0.616 & 0.011 & 1.852 \\
\hline \multicolumn{7}{|c|}{ Ethnicity (reference $=$ Lithuanian) } \\
\hline Polish & 0.081 & 0.008 & 1.084 & -0.256 & 0.008 & 0.774 \\
\hline Russian & 0.487 & 0.010 & 1.628 & 0.250 & 0.010 & 1.284 \\
\hline \multicolumn{7}{|c|}{ Education (reference $=$ primary) } \\
\hline Secondary & 0.077 & 0.012 & 1.080 & -0.109 & 0.010 & 0.896 \\
\hline Tertiary & -0.149 & 0.013 & 0.862 & 0.015 & 0.013 & 1.015 \\
\hline \multicolumn{7}{|c|}{ Occupational status (reference $=$ non-participating) } \\
\hline Low & 0.329 & 0.011 & 1.389 & 0.500 & 0.011 & 1.649 \\
\hline Middle & 0.245 & 0.010 & 1.277 & 0.574 & 0.011 & 1.775 \\
\hline High & -0.111 & 0.009 & 0.895 & 0.267 & 0.012 & 1.307 \\
\hline Unemployed & 0.263 & 0.012 & 1.301 & 0.313 & 0.013 & 1.368 \\
\hline Constant & 0.051 & 0.011 & 1.052 & 0.679 & 0.009 & 1.971 \\
\hline $\mathrm{R}^{2}$ (Negelkerke) & \multicolumn{3}{|l|}{0.070} & \multicolumn{3}{|l|}{0.033} \\
\hline$-2 \mathrm{LL}$ & \multicolumn{3}{|l|}{680,494} & \multicolumn{3}{|l|}{645,015} \\
\hline
\end{tabular}

Data source 2001 and 2011 Lithuanian censuses

Notes

$\mathrm{N}_{\text {total }}$ in $2011=533505, \mathrm{~N}_{\text {total }}$ in $2001=550441$

$\mathrm{N}_{\text {Soviet housing estates }}$ in $2011=330582, \mathrm{~N}_{\text {Soviet housing estates }}$ in $2001=393621$

Significance levels are not provided because the complete population sample is analysed

Lithuanian (reference category), Polish or Russian. We used the same set of independent characteristics. The results show that in Soviet-era apartments, ethnic minorities (especially Russians) are likely to be older compared to Lithuanians. It is likely that this also indicates that Lithuanians are more common among the newcomers. Ethnic minorities have a lower probability of having higher education (especially Poles). In addition, ethnic minorities are more likely to have lower occupational status or to be unemployed, and less likely to have higher occupational status than Lithuanians. It can be stated that in terms of socio-economic status, Russians are more similar to Lithuanians, while Poles occupy the most disadvantaged social positions in Vilnius Soviet-era apartments. It is interesting that when the same model is run for the rest of Vilnius population (table not shown), the differences between the ethnic groups are even higher. For example, ethnic minorities are more likely to be older (this probability is higher for Poles), they are more likely to be less educated (especially Poles) and to have more unfavourable positions in the 
Table 12.3 Multinomial logistic regression model of the Soviet housing estate population in Vilnius by ethnicity, 2011, at the individual level

\begin{tabular}{|c|c|c|c|c|c|c|c|c|}
\hline \multirow[b]{2}{*}{ Variables } & \multicolumn{4}{|l|}{ Poles } & \multicolumn{4}{|c|}{ Russians } \\
\hline & B & SE & \begin{tabular}{|l} 
EXP \\
(B)
\end{tabular} & $95 \% \mathrm{CI}$ & B & SE & $\begin{array}{l}\text { EXP } \\
\text { (B) }\end{array}$ & $95 \% \mathrm{CI}$ \\
\hline \multicolumn{9}{|c|}{ Gender $($ reference $=$ male $)$} \\
\hline Female & 0.222 & 0.010 & 1.249 & $1.224-1.274$ & 0.095 & 0.011 & 1.100 & $1.077-1.123$ \\
\hline \multicolumn{9}{|c|}{ Age (years) $($ reference $=$ up to 35) } \\
\hline $35-49$ & 0.473 & 0.015 & 1.605 & $1.559-1.651$ & 0.460 & 0.016 & 1.584 & $1.535-1.635$ \\
\hline $50-64$ & 0.551 & 0.014 & 1.734 & $1.687-1.783$ & 0.831 & 0.015 & 2.296 & $2.231-2.363$ \\
\hline Above 65 & 0.408 & 0.014 & 1.503 & $1.462-1.546$ & 0.685 & 0.015 & 1.984 & $1.926-2.044$ \\
\hline \multicolumn{9}{|c|}{ Education (reference $=$ primary) } \\
\hline Secondary & -0.279 & 0.017 & 0.757 & $0.732-0.782$ & 0.218 & 0.022 & 1.244 & $1.192-1.298$ \\
\hline Tertiary & -1.323 & 0.021 & 0.266 & $0.256-0.277$ & -0.087 & 0.024 & 0.916 & $0.875-0.960$ \\
\hline \multicolumn{9}{|c|}{ Occupational status (reference $=$ non-participating) } \\
\hline Low & 0.627 & 0.017 & 1.872 & $1.812-1.933$ & 0.290 & 0.018 & 1.336 & $1.289-1.385$ \\
\hline Middle & 0.162 & 0.016 & 1.176 & $1.139-1.215$ & -0.071 & 0.018 & 0.931 & $0.899-0.965$ \\
\hline High & -0.273 & 0.019 & 0.761 & $0.733-0.790$ & -0.533 & 0.019 & 0.587 & $0.565-0.609$ \\
\hline Unemployed & 0.399 & 0.020 & 1.491 & $1.435-1.549$ & 0.445 & 0.020 & 1.561 & $1.500-1.623$ \\
\hline Intercept & \multicolumn{4}{|l|}{-1.214} & \multicolumn{4}{|l|}{-1.975} \\
\hline
\end{tabular}

Data source 2001 and 2011 Lithuanian censuses

Notes

Lithuanians constitute the reference category

$\mathrm{N}_{\text {total }}=301701, \mathrm{~N}_{\text {Lithuanians }}=197067, \mathrm{~N}_{\text {Poles }}=57593, \mathrm{~N}_{\text {Russians }}=47041$

-2 Log-likelihood final $=6307.051 . \mathrm{R}^{2}$ (Nagelkerke) $=0.088$

Significance levels are not provided because the complete population sample is analysed

labour market. More detailed analysis by housing type would help to gain further insights into residential differentiation in Vilnius. The model for 2001 (table not shown) suggests that differences between the main ethnic groups have tended to decline in recent decades. For example, the probability of Poles having higher occupational status increased from 0.619 to 0.761 and for Russians, it increased from 0.454 to 0.587 . Similarly, the probability of having tertiary education increased from 0.201 to 0.266 for Poles and from 0.893 to 0.916 for Russians.

Summarising, we find that the social structure of Soviet-era apartment buildings is marked by a relative decline. They are becoming more ethnically mixed but differences between ethnic groups are decreasing. These trends are logical trends in light of the share of Soviet-era dwellings in the housing stock, the minimal differences in its attractiveness and the available alternatives (both positive and negative). 


\subsection{Discussion and Conclusion}

In this chapter, we sought to learn more about the social and ethnic profile of the residents of Soviet housing estates in Vilnius and to highlight the trajectories of change. Our results show that in terms of their socio-ethnic structure Soviet housing estates are more homogenous spaces compared with the rest of the city. The results also show that the socio-ethnic structure of these residential areas varies depending on their location and construction period. On the other hand, there are significant socio-economic differences between ethnic groups in Soviet housing estates, although these have been gradually decreasing in recent decades. Most likely these differences, especially the positions of ethnic minorities in the labour market, were inherited from the Soviet period. We assume that similar housing conditions and locations, nowadays, play their role in reducing residential differentiation in Soviet housing estates (attracting residents of similar purchasing power). Although socio-ethnic differentiation is also decreasing on a city-wide scale, this decrease is faster in Soviet housing estates.

Soviet housing estates tend to maintain ethnically mixed populations, whereas the city as a whole is becoming more Lithuanian. We may expect that this ethnic differentiation will continue in the decades to come. There are no signs that Soviet housing estates could become ethnically segregated, but such trends are visible in some working-class neighbourhoods, which are becoming the last place of choice for the residents.

Our results also show that the demographic and socio-economic composition of Soviet housing estate districts and neighbourhoods is tending to deteriorate in relation to the rest of the city. One of the most outstanding features of these areas is an increasing overrepresentation of older population groups. While the most prosperous and younger population groups prefer to live in other parts of the city, older residents are 'ageing in place' in Soviet housing estates; as a result, new residents have limited opportunities to move in. Although we do not predict any major changes in socio-ethnic composition in Soviet housing estates, it might start to change when the rapidly ageing population starts to pass away. In addition, the majority of Vilnius residents live in Soviet-era apartments; thus, it is unlikely that there will be a sudden social downturn. Soviet housing estates do not differ significantly in their attractiveness, but somewhat faster negative trends are evident in older and more distant areas.

There are several reasons that explain why Soviet-era housing estates do not devolve into the least attractive residential areas in Vilnius: (1) their dominance of the housing stock; (2) lower quality housing in the working-class neighbourhoods, dormitories and industrial suburbs; (3) minimal differences in the attractiveness and prices of dwellings in Soviet housing estates (preventing the concentration of low-income groups in particular areas); (4) the current social structure of Soviet housing estates; (5) the relatively low share of ethnic minorities in Soviet housing estates and in the city; (6) the decreasing number and share of low-skilled and unemployed residents in Vilnius. 
A new development tool, the "Neighbourhoods programme", presented by the city government in 2017, aims at revitalisation initiatives for Soviet-planned areas (Vilnius City Municipality 2018) and 1288 neighbourhoods, consisting of Soviet-era apartment buildings, were defined. Financial aid is provided to those neighbourhoods, whose communities actively cooperate. This programme is in its initial phase and therefore, it is difficult to predict its success and effect. The older population composition of Soviet-era apartments may have a negative effect on revitalisation projects because the participation of active local communities is very important. The uneven spatial distribution of renovation projects also indicates the presence of residential (social) differentiation among the residents in Soviet housing estates. In Vilnius, the revitalisation of Soviet housing estates could be facilitated by the active involvement of city government in the development of infrastructure; For example, additional car parking places, improvement of transport junctions, creation of sites attractive for small businesses and group renovation of housing.

\section{References}

Andersson R, Kährik A (2016) Widening gaps: segregation dynamics during two decades of economic and institutional change in Stockholm. In: Tammaru $\mathrm{T}$ et al (eds.) Socio-economic segregation in European capital cities. East meets west. Routledge, London, pp 110-131

Bolt G, van Kempen R (2010) Ethnic segregation and residential mobility: relocations of minority ethnic groups in the Netherlands. J Ethn Migr Stud 36(2):333-354

Borén T, Gentile M (2007) Metropolitan processes in post-communist states: an introduction. Geografiska Ann Ser B Hum Geogr 89(2):95-110

Burneika D, Ubarevičienè R (2016) Socio-ethnic segregation in metropolitan areas of Lithuania. Czech Sociol Rev 52(6):795-819

Burneika D (2008) Post-Soviet transformations of urban space in Vilnius. Ann Geogr 41(1-2):1425

Burneika D, Ubarevičienė R, Valatka V, Baranauskaitė A, Pociūtė-Sereikienė G, Daugirdas V, Krupickaitė S (2017) Lietuvos metropoliniai regionai. Gyventojų rezidencinè diferenciacija XXI a. pradžioje [The metropolitan regions in Lithuania. Residential differentiation in 21st century]. LSTC, Vilnius

Čiurlionienė I (2008) Vilniaus miesto planavimo raida: kai kurie estetinių aspektų ypatumai [The evolution of Vilnius city planning: some peculiarities of the aesthetic aspect]. In: K. Šešelgio skaitymai [K. Šešelgis readings] conference. VGTU, Vilnius

Gentile M, Tammaru T, van Kempen R (2012) Heteropolitanization: social and spatial change in central and East European cities. Cities 29(5):291-299

International Standard Classification of Occupations. http://www.ilo.org/wcmsp5/groups/public/dgreports/—dcomm/—publ/documents/publication/wcms_172572.pdf. Accessed 9 May 2016

Krupickaitė D (2014) Vilnius - between persistence and socio-spatial change. Eur Reg 19(34):21-31

Krišjāne Z, Bērziņš M, Kratovitš K (2016) Occupation and ethnicity: Patterns of residential segregation in Riga two decades after socialism. In: Tammaru $\mathrm{T}$ et al (eds) Socio-economic segregation in European capital cities: east meets west. Routledge, London, pp 287-312

Ščerbinskaitė S, Krupickaite D (2017) Daugiabučiu renovacijos Vilniaus mieste teritoriniai ypatumai [Territorial features of renovation of apartment buildings in Vilnius]. Geografijos metraštis 50:21-40 
Semyonov M, Glikman A (2009) Ethnic residential segregation, social contacts, and anti-minority attitudes in European societies. Eur Sociol Rev 25(6):693-708

Šešelgis K (1996) Teritorijų planavimo raida Lietuvoje [Development of regional planning in Lithuania]. Urbanistika Ir Architektūra 21(1):4-19

Statistics Lithuania (2001) Census data, on special request

Statistics Lithuania (2011) Cendus data, on special request

Sýkora L, Ouředníček M (2007) Sprawling post-communist metropolis: commercial and residential suburbanization in Prague and Brno, the Czech Republic. In: Razin E et al (eds) Employment deconcentration in European metropolitan areas. Springer, Dordrecht, pp 209-233

Tammaru T, Kahrik A, Magi K, Novák J, Leetmaa K (2016) The 'market experiment': increasing socio-economic segregation in the inherited bi-ethnic context of Tallinn. In: Tammaru $\mathrm{T}$ et al (eds) Socio-economic segregation in European Capital cities: East meets West. Routledge, London, pp 333-358

Tereškinas A, Žilys A, Indiliūnaitė R (2013) Pilietiškumas ir tapatumas šiuolaikinėje visuomenėje: Socialinè atskirtis ir socialinè segregacija Lietuvos didmiesčiuose [Citizenship and identities in contemporary society: Social exclusion and social segregation in Lithuanian cities]. Vytauto Didžiojo Universiteto Mokslo Klasteriai 2:171-185

Ubarevičienė R, van Ham M, Burneika D (2016) Shrinking regions in a shrinking country: the geography of population decline in Lithuania 2001-2011. Urban Stud Res 1-18

Valatka V, Burneika D, Ubarevičiené R (2016) Large social inequalities and low levels of socio-economic segregation in Vilnius. In: Tammaru $\mathrm{T}$ et al (eds) Socio-economic segregation in European capital cities: east meets west. Routledge, London, pp 313-332

Vanagas J (1996) Miesto sociologijos pagrindai [Basics of urban sociology]. Technika, Vilnius

Žilys A (2013) Rezidencinè diferenciacija ir skirtumai Lietuvos moderniajame mieste: (po) sovietinis ar Vakaru miestas? [Residential differentiation in Lithuanian modern cities: Is it a (post-)Soviet or Western city?] Socialinių tyrimų žurnalas 4(2): 67-101

Vilnius City Municipality (2018) About the Neighbourhoods programme. https://www.vilnius.lt/ kaimynijos. Accessed 13 Mar 2018

Open Access This chapter is licensed under the terms of the Creative Commons Attribution 4.0 International License (http://creativecommons.org/licenses/by/4.0/), which permits use, sharing, adaptation, distribution and reproduction in any medium or format, as long as you give appropriate credit to the original author(s) and the source, provide a link to the Creative Commons license and indicate if changes were made.

The images or other third party material in this chapter are included in the chapter's Creative Commons license, unless indicated otherwise in a credit line to the material. If material is not included in the chapter's Creative Commons license and your intended use is not permitted by statutory regulation or exceeds the permitted use, you will need to obtain permission directly from the copyright holder. 